\title{
IMPLEMENTASI DATA KEUANGAN DENGAN ZAHIR ACCOUNTING PADA PT. ANUGERAH ANALISIS SEMPURNA
}

\author{
Susan Rachmawati ${ }^{1)}$; Nurjanah ${ }^{2)}$ \\ ${ }^{1)}$ AMK BSI Jakarta; ${ }^{2)}$ AMIK BSI Jakarta \\ ${ }^{1)}$ susan.srw@bsi.ac.id; ${ }^{2)}$ nurjanahsuardi@gmail.com
}

\begin{abstract}
Abstrak
Dengan banyaknya data transaksi yang terjadi, jika pendataan dilakukan secara manual banyak waktu yang terbuang untuk pengolahan data keuangan.Karena banyak tahap yang harus dikerjakan untuk dapat menghasilkan laporan keuangan. Data yang dihasilkan pun belum tentu akurat dan sesuai.aplikasi akuntansi telah diciptakan untuk memudahkan dalam mengambil keputusan atas bisnis yang dijalankan. Penggunaan aplikasi komputer akuntansi sangatlah efisien dan efektif bagi seorang pengusaha ataupun pedagang dalam menjalankan bisnisnya. Pengolahan data keuangan yang hanya tinggal input data transaksi saja, sudah dapat menghasilkan laporan yang diinginkan untuk pengambilan keputusan. Dengan menggunakan Zahir Accounting kemudahan yang diberikan yaitu memang dirancang sesederhana mungkin agar penggunanya dapat dengan mudah memahami fitur yang disediakan. Dalam pengolahan data yang telah diinput langsung membentuk jurnal dan juga laporan keuangan.
\end{abstract}

Kata Kunci : Akuntansi, Aplikasi, Implementasi, Zahir Accounting

\begin{abstract}
With the number of data transactions that occur, if data collection is done manually much time wasted for financial data processing. Because many stages to be done to be able to produce financial statements. The resulting data is not necessarily accurate and appropriate. Accounting applications have been created to facilitate in making decisions on the business run. The use of computer accounting applications is very efficient and effective for a businessman or a trader in running his business. Processing financial data that only live input transaction data alone, can produce the desired report for decision making. By using Zahir Accounting the ease given is indeed designed as simple as possible so that users can easily understand the features provided. In the processing of data that has been inputted directly form the journal and also the financial statements.
\end{abstract}

Keywords: Accounting, Application, Implementation, Zahir Accounting

\section{PENDAHULUAN}

Pengolahan data transaksi secara manual tidak menjadi masalah, tetapi yang jadi masalah apabila banyaknya transaksi yang ada menggunakan sistem pencatatan manual. Hal tersebut akan menghambat jalannya usaha, karena banyaknya transaksi yang harus diinput, serta tahapan-tahapan lainnya yang harus dibuat, jika menggunakan pencatatan secara manual. Seperti saat melakukan penginputan transaksi, setelah diinput di dalam jurnal maka langkah selanjutnya yaitu membuat buku besar, kemudian berdasarkan buku besar baru didapat neraca saldo. Hasil laporan keuangan belum bisa dihasilkan karena masih ada tahapan penyesuaian serta menyusun neraca lajur. Informasi yang diberikan dengan sistem pencatatan manual pun belum sepenuhnya dipercaya, karena adanya kemungkinan double entry terhadap transaksi yang dimasukkan. Rentannya kesalahan atau resiko yang didapat, apabila transaksi yang banyak tetapi masih menggunakan sistem pencatatan atau pengolahan data yang manual. Menyebabkan pengolahan data secara terkomputerisasi lebih disarankan.

Zahir Accounting versi 5.1 adalah software akuntansi yang digunakan untuk membuat laporan keuangan, dengan bahasa yang mudah dipahami dan dimengerti. Penggunaan Zahir Accounting yang hanya tinggal input saja tanpa harus membuat tahapan yang dilakukan dalam pencatatan manual 
sudah dapat menghasilkan laporan yang diinginkan. Menggunakan Zahir Accounting versi 5.1, seluruh proses pembuatan jurnal, pencatatan kartu hutang dan piutang usaha, mencatat pemakaian barang dan menghitung harga pokok barang, serta perhitungan penyusutan dan pembuatan laporan keuangan dilakukan secara otomatis. Seluruh data yang telah diisi akan disimpan dan digunakan kembali pada transaksi-transaksi yang lain.

\section{KAJIAN PUSTAKA}

Akuntansi

Menurut Yulius (2011) mendefinisikan bahwa "Akuntansi merupakan proses identifikasi, pencatatan dan pelaporan seluruh transaksi atau kejadian ekonomi yang terjadi dalam suatu perusahaan".

Menurut Dunia (2008) mendefinisikan bahwa "Akuntansi adalah sebagai suatu sistem informasi yang memberikan laporan kepada berbagai pemakai atau pembuat keputusan mengenai aktivitas bisnis dari suatu kesatuan ekonomi”.

Siklus Akuntansi

Menurut Mulya (2013) mendefinisikan bahwa "Siklus akuntansi merupakan proses pencatatan akuntansi mulai dari dokumen sampai penyajian laporan keuangan".

Menurut Rudianto (2012) mendefinisikan bahwa "Siklus Akuntansi adalah aktivitas mengumpulkan, menganalisis, menyajikan dalam bentuk angka, mengklasifikasikan, mencatat, meringkas, dan melaporkan aktivitas atau transaksi perusahaan dalam bentuk informasi keuangan”.

Menurut Suradi (2009) mendefinisikan bahwa "Proses akuntansi yang dimulai dari identifikasi dan analisa transaksi dan diakhiri menyusun laporan keuangan disebut siklus akuntansi”.

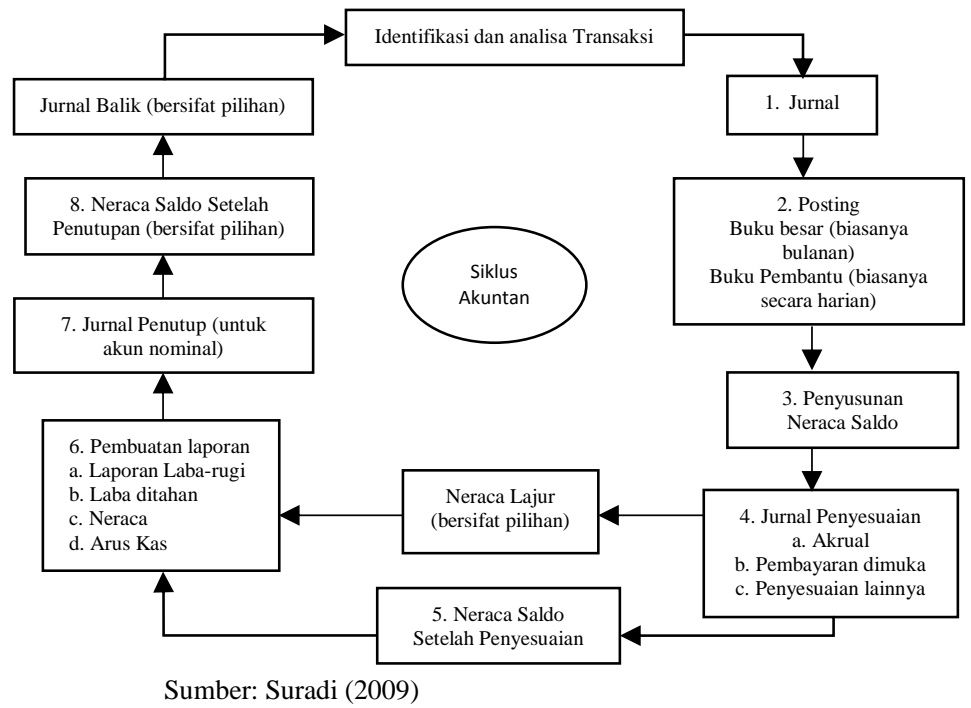

Gambar 1. Siklus Akntansi
Zahir Accounting

Menurut Yuswanto dan Hanafi (2013) mendefinisikan bahwa "Zahir Accounting merupakan software akuntansi yang dibuat secara terpadu (integrated software)".

Keunggulan Zahir Accounting versi 5.1 menurut Yuswanto dan Hanafi (2013), yaitu:

a) Tampilan yang menarik baik dalam interface program maupun dalam penyajian laporan keuangan.

b) Berbagai menu yang memudahkan pencatatan.

\section{METODE PENELITIAN}

Dalam proses pengumpulan datanya, penulis melakukan penelitian dengan cara sebagai berikut:

1. Observasi

Penulis melakukan observasi dengan mengunjungi dan melihat secara langsung ke PT Anugerah Analisis Sempurna di JL. Raya Jakarta - Bogor KM. 37, Depok dan pengamatan yang dilakukan khususnya pada bagian keuangan.

2. Interview

Teknik penulis mengumpulkan data dengan cara wawancara atau melakukan tanya jawab dengan pihak yang terkait didalam perusahaan mengenai data-data yang akan penulis sampaikan pada penulisan ini. Wawancara dilakukan kepada staf Keuangan yaitu ibu Siska Elfrida.

3. Studi Pustaka

Penulis mengumpulkan data berdasarkan sumber-sumber yang biasa di gunakan untuk penulisan karya tulis (literatur-literatur) yang berkaitan dengan pengolahan data transaksi keuangan.

\section{HASIL DAN PEMBAHASAN}

PT Anugerah Analisis Sempurna atau AAS Laboratory, merupakan laboratorium independen yang mempunyai fokus utama dalam bidang jasa analisis untuk parameter - parameter: yaitu keamanan pangan (food safety), validasi metode pengembangan produk farmasi atau sejenisnya, lingkungan, dan kesehatan lingkungan kerja (industrial hygiene) serta biomonitoring.

Permasalahan yang dihadapi yaitu transaksi yang banyak tetapi pengolahan datanya masih manual, berupa pencatatan piutang dan hutang usaha serta penerimaan dan pengeluaran dari PT Anugerah Analisis Sempurna lainnya yang menggunakan excel. Pengolahan data yang ada menjadi tidak efesien dan efektif, karena adanya kesalahan input serta banyaknya tahapan-tahapan yang harus dibuat jika menggunakan pengolahan data yang manual.

Maka dari itu, penulis menggunakan program aplikasi dengan Zahir Accounting Versi 5.1. yang dapat mempermudah sistem pembuatan laporan keuangan. Zahir Accounting Versi 5.1. yang sudah 
terprogram, hanya satu langkah penginputan sudah dapat menghasilkan laporan yang diinginkan. Alasan dipilihnya Zahir Accounting Versi 5.1. karena aplikasi ini sederhana dan lebih mudah dipelajari serta sesuai dengan transaksi yang ada di PT anugerah Analisis Sempurna.

1. Membuat kode akun

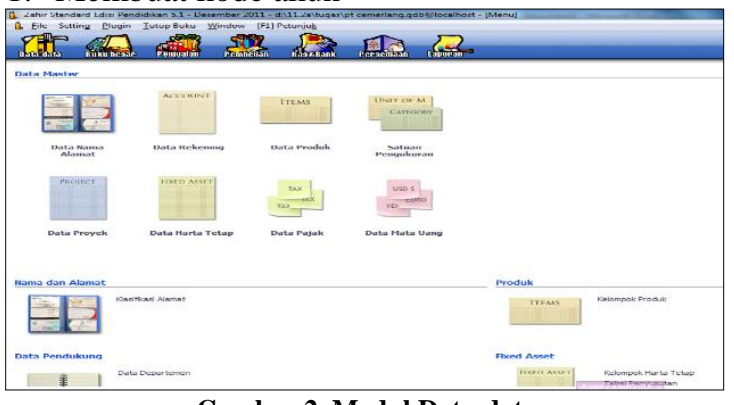

Gambar 2. Modul Data-data

Pilih Modul Buku Besar pilih Data Rekening Perkiraan

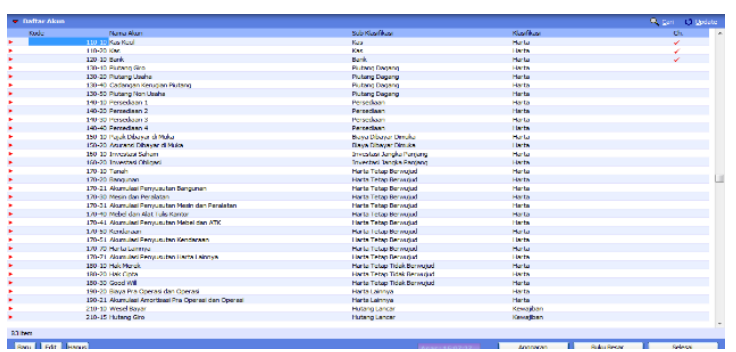

Gambar 3. Data Rekening Perkiraan

Menambah Data Akun Baru, Pada jendela Daftar Akun, klik tombol Baru. Pilih klasifikasi akun sesuai dengan akun yang akan ditambahkan, kemudian isiskan kode sesuai dengan data. Ceklis tanda kas/bank jika akun tersebut merupakan klasifikasi kas/bank. Klik rekam jika sudah sesuai.

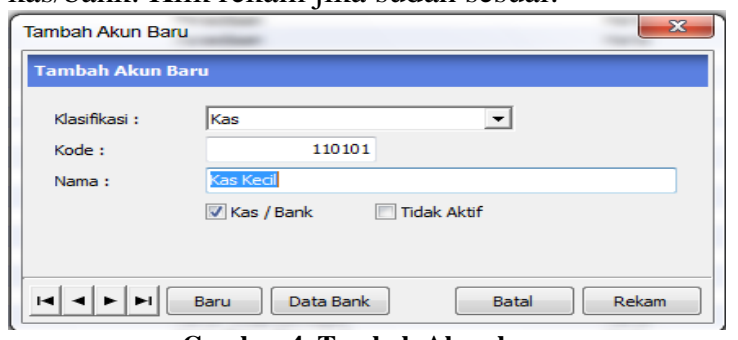

Gambar 4. Tambah Akun baru

2. Link account

Pilih Modul Buku Besar pilih Data Mata Uang

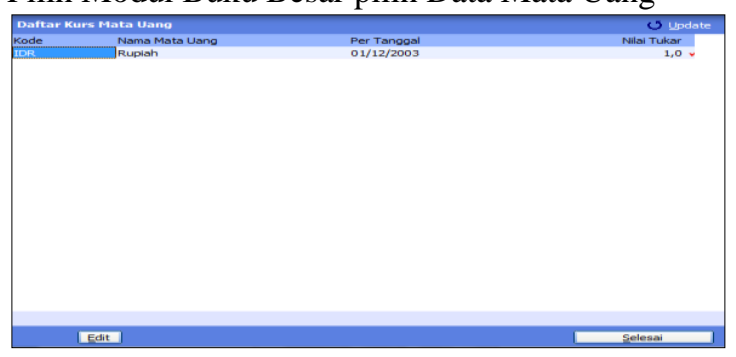

Gambar 5. Daftar Kurs Mata Uang
Edit kemudian pilih menu tab Akun Penting. Kemudian jika ingin merubah akun yang bersangkutan klik simbol mouse untuk memilih akun.

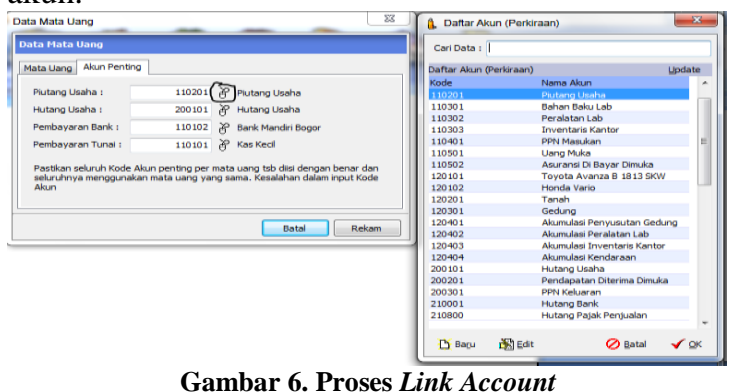

Pilih akun untuk masing-masing menu.Jika sudah sesuai klik rekam.

\section{Setup inventory}

Pilih Modul Buku Besar pilih kelompok harta tetap. Klik tombol Baru. Kemudian isikan data. Berikan centang pada field, menandakan penyusutan dihitung berdasarkan tanggal perolehan. Jika tanggal perolehan di atas tanggal 15 maka akan dibebankan pada bulan berikutnya. Klik Rekam jika sudah sesuai.

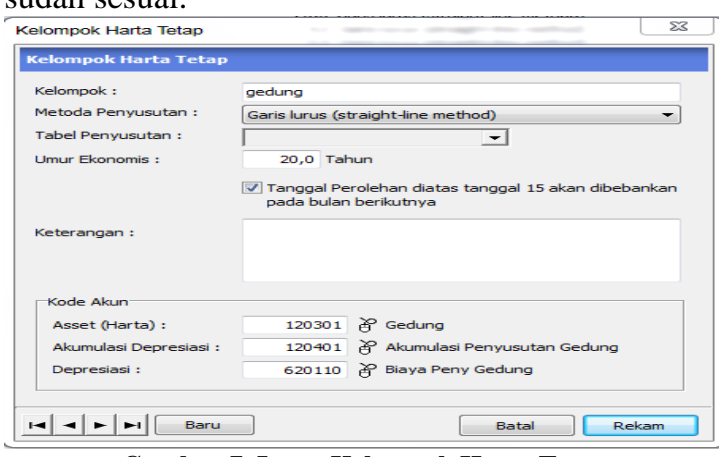

Gambar 7. Input Kelompok Harta Tetap

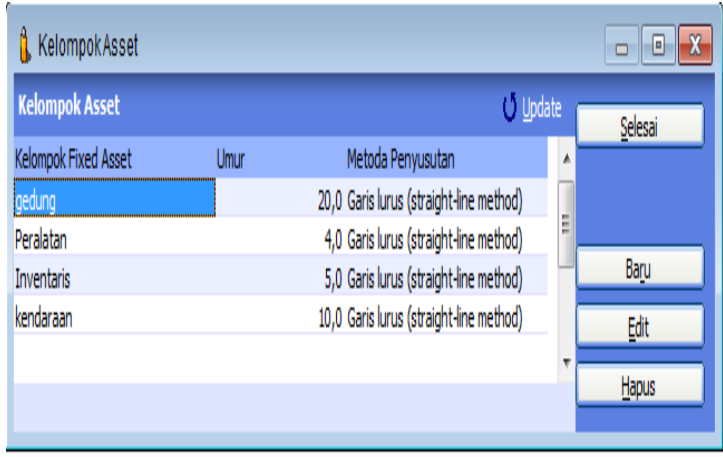

Gambar 8. Daftar Kelompok Harta Tetap

4. Input saldo awal

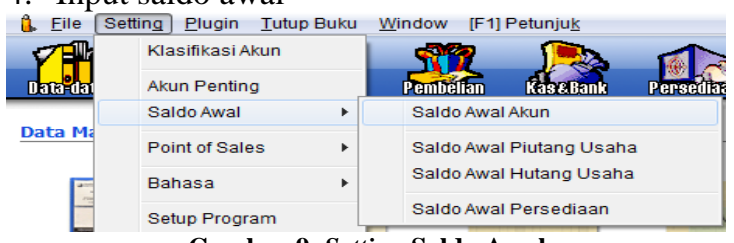

Gambar 9. Setting Saldo Awal 
Isikan saldo awal sesuai dengan akun, hingga nilai sebesar berada diangka Rp 0 (lihat gambar 10). Kemudian jika sudah sesuai klik rekam.

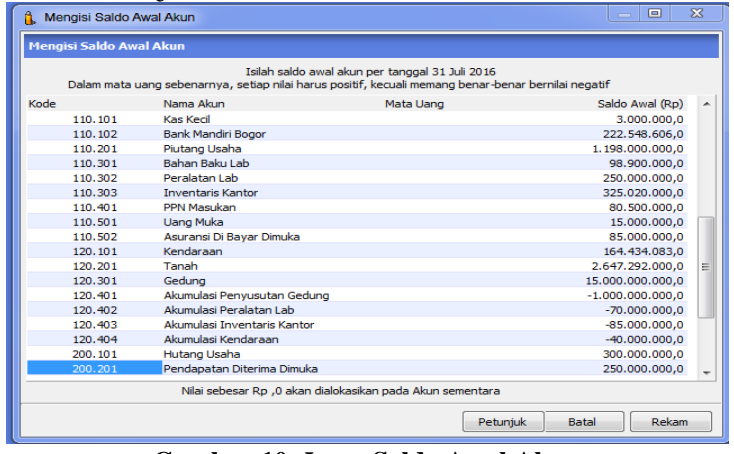

Gambar 10. Input Saldo Awal Akun

5. Form saldo awal piutang

Pilih menu bar Setting, pilih menu saldo awal kemudian pilih saldo awal piutang usaha.

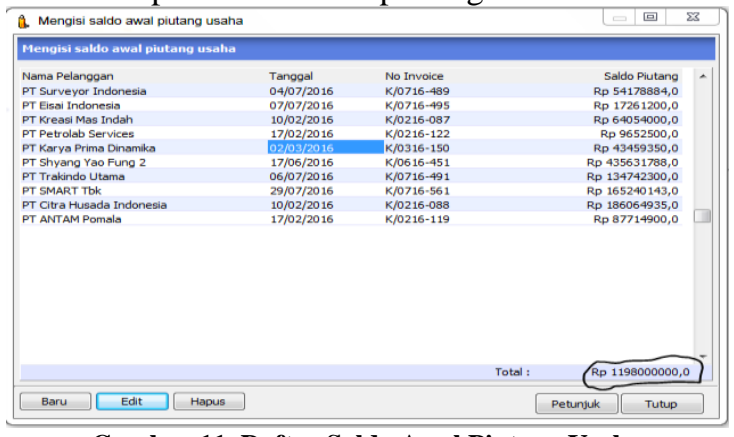

Gambar 11. Daftar Saldo Awal Piutang Usaha

6. Form saldo awal hutang

Pilih menu bar Setting, pilih menu saldo awal kemudian pilih saldo awal hutang usaha.

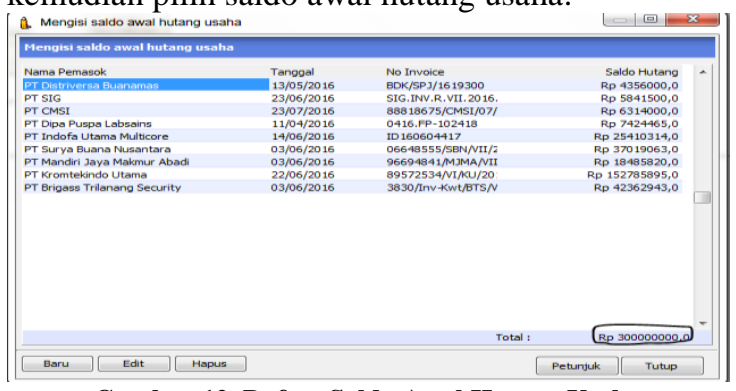

Gambar 12. Daftar Saldo Awal Hutang Usaha

7. Input data transaksi

Berikut ini beberapa contoh transaksi keuangan yang terjadi di PT Anugerah Analisis Sempurna:

Tanggal 1 Agustus 2016 dengan No. Bukti: BK/1608-001 Pengisisan kas kecil melalui Bnak Mandiri Bogor sebesar Rp 5.000.000,00

Langkahnya yaitu pilih modul Kas\&Bank kemudian pilih Form Transfer Kas. Isikan form sesuai bukti transaksi. Jika sudah sesuai klik rekam.

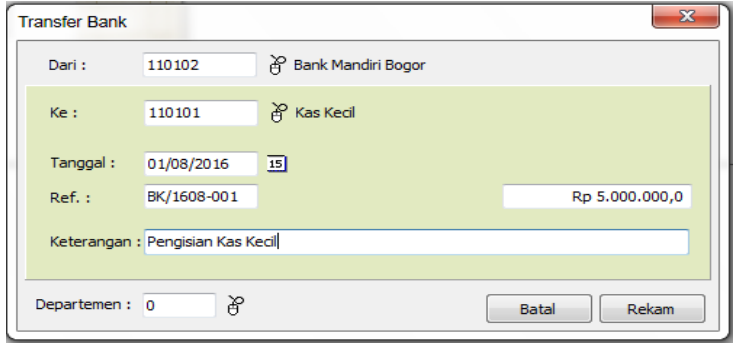

Gambar 13. Input Transaksi BK/1608-001

Tanggal 1 Agustus 2016 dengan No. Bukti BK/1608-002 Biaya Kalibrasi Gas Detevtor Lab Sucofindo No.06778/LAB-VII/PDO/2016 ditambah PPN 10\% dan Beban bank melalui bank Mandiri Bogor Rp 4.500.000,00

Langkahnya yaitu pilih modul Kas \& Bank kemudian pilih Form Kas Keluar. Isikan form sesuai bukti transaksi. Jika sudah sesuai klik rekam.

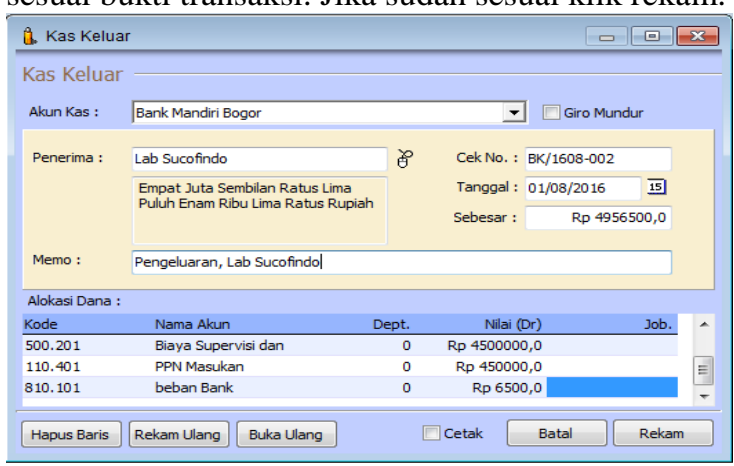

Gambar 14. Input Transaksi BK/1608-002

Tanggal 1 Agustus 2016 dengan No Bukti: BK/1608-006 Perusahaan melakukan pembayaran hutang kepada PT Indofa Utama Multicore dengan nomor ID16060441 melalui bank Mandiri Bogor Rp 25.410.314,00

Langkahnya yaitu pilih modul Pembelian kemudian pilih form Pembayaran Hutang Usaha. Isikan form sesuai bukti transaksi. Jika sudah sesuai klik rekam.

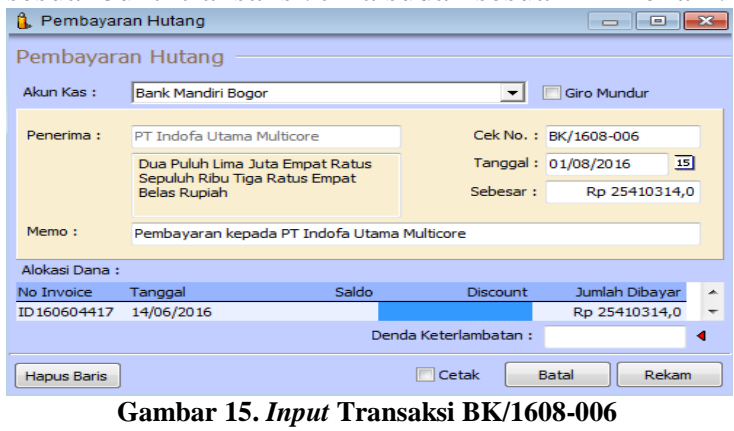

Tanggal 1 Agustus 2016 dengan No. Bukti BT/1608-001 Penerimaan pembayaran piutang dari PT Surveyor Indonesia dengan nomor invoice K/0716-489 melalui bank mandiri bogor sebesar Rp 27.089.442,00

Langkahnya yaitu pilih modul Penjualan kemudian pilih form Pembayaran Piutang Usaha. Isikan form sesuai bukti transaksi. Jika sudah sesuai klik rekam. 


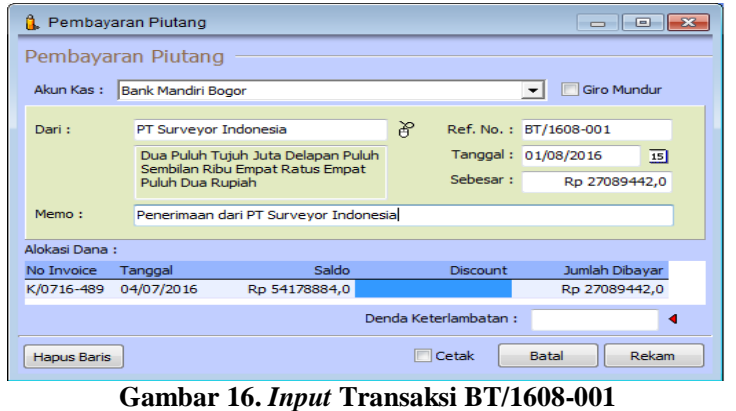

Tanggal 3 Agustus 2016 dengan No. Bukti BK/1608-011 Pembelian tunai botol coklat $125 \mathrm{ml}$ kepada CV Aryta Jaya Packaging dengan nomor invoice NoPJ/AM/160728) Rp 690.000,00 ditambah beban bank, melalui bank Mandiri Bogor Rp $6.500,00$

Langkahnya yaitu pilih modul Pembelian kemudian Pilih form penerimaan Barang. Jika transaksi secara tunai dan barang yang dibeli bukan untuk dijual maka ceklis invoice, jasa dan tunai.

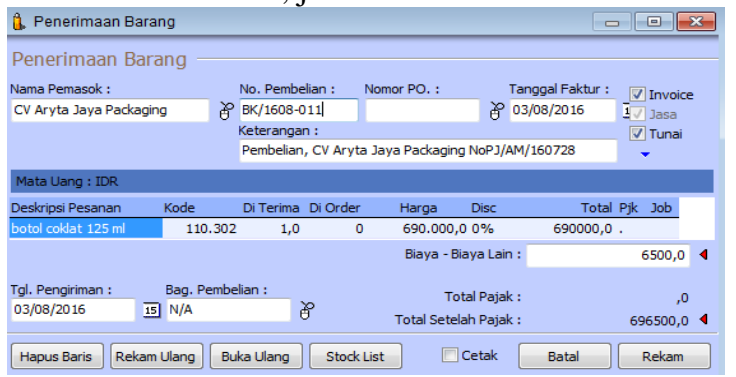

Gambar 17. Input Transaksi BK/1608-011

Tanggal 4 Agustus 2016 dengan No. Bukti AR/1608-001 Pendapatan jasa secara kredit oleh PT Tanjung Sawit Abadi dengan nomor invoice K/0816-562 Rp 675.000,00 ditambah PPN 10 \% Rp $67.500,00$

Langkahnya yaitu pilih modul Penjualan kemudian pilih form Pengiriman Barang (invoicing). Jika transaksi secara kredit dan merupakan jasa maka ceklis invoice dan jasa.

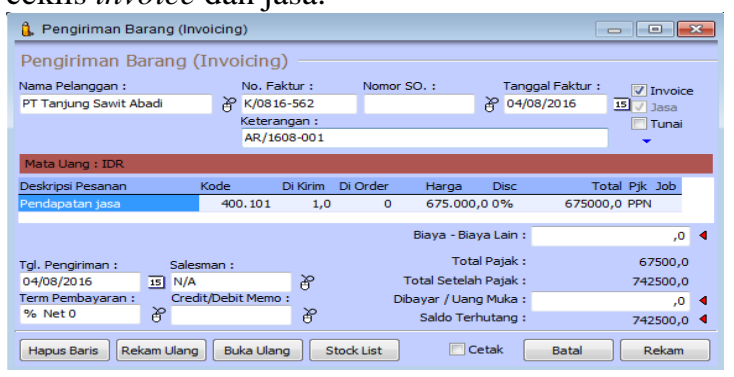

Gambar 18. Input Transaksi AR/1608-001

Tanggal 8 Agustus 2016 dengan No. Bukti MM/1608-001 Pertanggung jawaban UM/1608-001 Pick Up sample CBI digudang Cargo dan Soetta (Asep) melalui uang muka Rp 1.210.000,00

Langkahnya yaitu pilih modul Buku Besar dan kemudian pilih form Transaksi Jurnal Umum. Isikan form sesuai bukti transaksi. Jika sudah sesuai klik rekam.

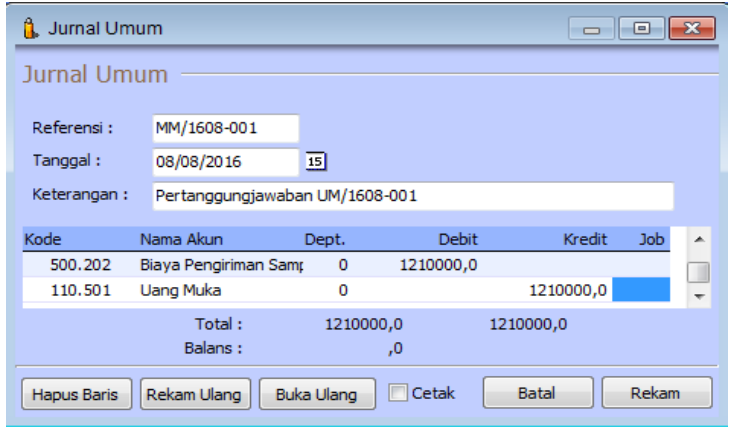

Gambar 19. Input Transaksi MM/1608-001

8. Transaksi Ayat Jurnal Penyesuaian

Tanggal 31 Agustus 2016 dengan No. Bukti MM/1608-007 Asuransi bulan Agustus 2016 yang terpakai Rp 15.020.150,00

Langkahnya yaitu pilih modul Buku Besar dan kemudian pilih form Transaksi Jurnal Umum. Isikan form sesuai bukti transaksi. Jika sudah sesuai klik rekam.

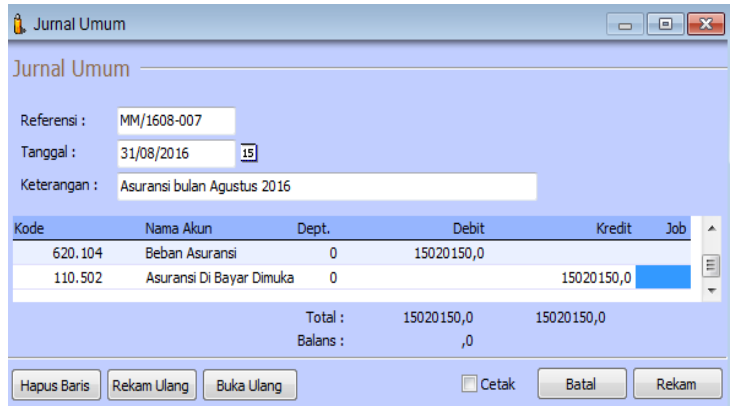

Gambar 20. Input Transaksi MM/1608-007

Tanggal 31 Agustus 2016 dengan NO. Bukti MM/1608-008 penyusutan gedung Rp 50.0000.000,00 Penyusutan Peralatan Lab Rp 4.375.000,00 Penyusutan Inventaris Kantor $\mathrm{Rp}$ 5.000.000,00 Penyusutan Kendaraan Rp $1.000 .000,00$

Langkahnya yaitu pilih modul Buku Besar dan kemudian pilih form Transaksi Jurnal Umum. Isikan form sesuai bukti transaksi. Jika sudah sesuai klik rekam.

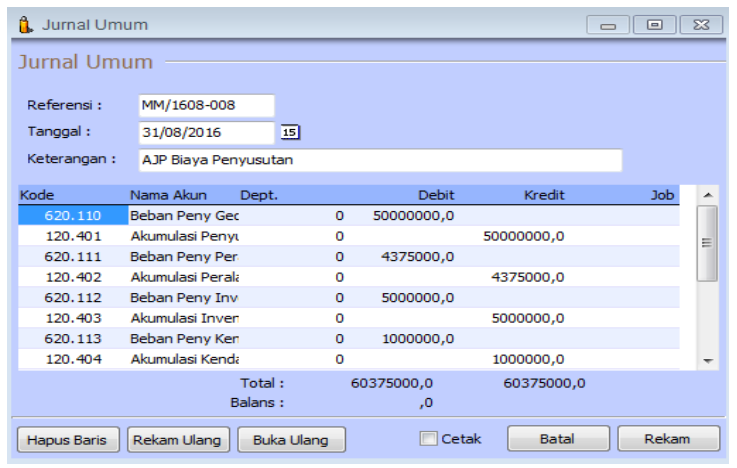

Gambar 21. Input Transaksi MM/1608-008 
9. Lap keuangan

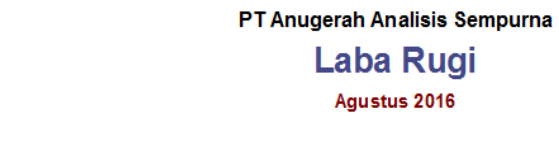

Pendapatan

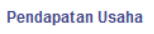

$\begin{array}{ll}400.101 & \text { Pendapatan Jasa } \\ 400.102 & \text { Pendapatan Subkon }\end{array}$

Total Pendapatan

Biaya atas Pendapatan

Biaya Produksi

500.101 Biaya Upah dan Honor

500.102 Biaya Pegawai Analis

500.201 Biaya Supervisi dan Kalibrasi

500.202 Biaya Pengiriman Sampel
500301
Biaya Operasional Sampling

Total Biaya Produksi

Total Biaya atas Pendapatan

Laba/Rugi Kotor

Pengeluaran Operasional

Biaya Operasiona

610.101 Beban Listrik

610.201
610.301
Bebanan Telekekomunikas

610.401 Beban Pen

$\begin{array}{ll}610.501 & \text { Beban Materai dan Benda Pos } \\ 610.601 & \text { Beban Perlengkapan Kantor }\end{array}$

610.601
611.201
611.301
6 Beban Rum Rumah Tangaga dan Un
Beban ATK dan Photo Copy

401 Beban PDAM

Total Biaya Operasional

Biaya Non Operasiona

611.101 Beban Sumbangan
611.501

$\begin{array}{ll}61.501 & \text { Beban Bumbangan } \\ 620.102 & \text { Beban Catering dan Mar } \\ 62.10 & \end{array}$

$\begin{array}{ll}620.102 & \text { Beban Catering daan } \\ 620.103 & \text { Beban Keseratan } \\ 620.104 & \text { Beban Asuransi }\end{array}$

620.105 Beban Training dan Seminar
620.106 Beban Fee Audit Eksternal
620.107

$\begin{array}{ll}620.106 & \text { Beban Fee Audit Eksternal } \\ 620.107 & \text { Beban Pemelinaraan Kendaraa } \\ 620.108 & \text { Beban Operasional Marketing }\end{array}$

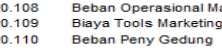

Beban Peny Peralatan lab
620.111
620.112
Beban Peny Inventaris Toko

620.113
Total Biaya Non Operasional

Pengeluaran Operasional

Laba/Rugi Operasi

Pendapatan Lain
Pendapatan Luar Usana

710.101 Pendapa:an 3ung
Total Pendapatan Luar Usaha

Total Pendapatan Lain

Pengeluaran Lain

Pengeluaran Luar Usaha

810.101 beban 3ank
Total Pengeluaran Luar Usaha

Total Pengeluaran Lain

Laba/Rugi Bersih

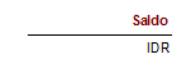

238.290.025.00

267.883.025.00

267.883.025.00

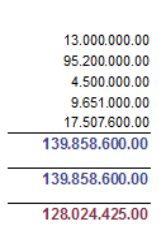

33.656 .411 .00

822.500 .00

1.349 .411 .00
215.000 .00

900.000 .00
3.317 .000 .00

2.937345 .00

2.020 .173 .00
13.027 .450 .00

40.002000 .00
98.247 .290 .00

900.000 .00
388.000 .00

3.940 .000 .00
846.068 .00

15.020 .150 .00
4.000 .000 .00

4.000 .000 .00
48.0000

210.000 .00
550.00000

50.000 .000 .00

4.375 .000 .00
5.000 .000 .00

$\frac{1.000 .000 .00}{17.277 .218 .00}$

$\begin{array}{r}\text { Saido } \\ \hline 215.524 .508 .00 \\ \hline\end{array}$

$-87.500 .083 .00$

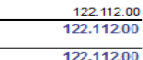

122.11200

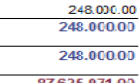

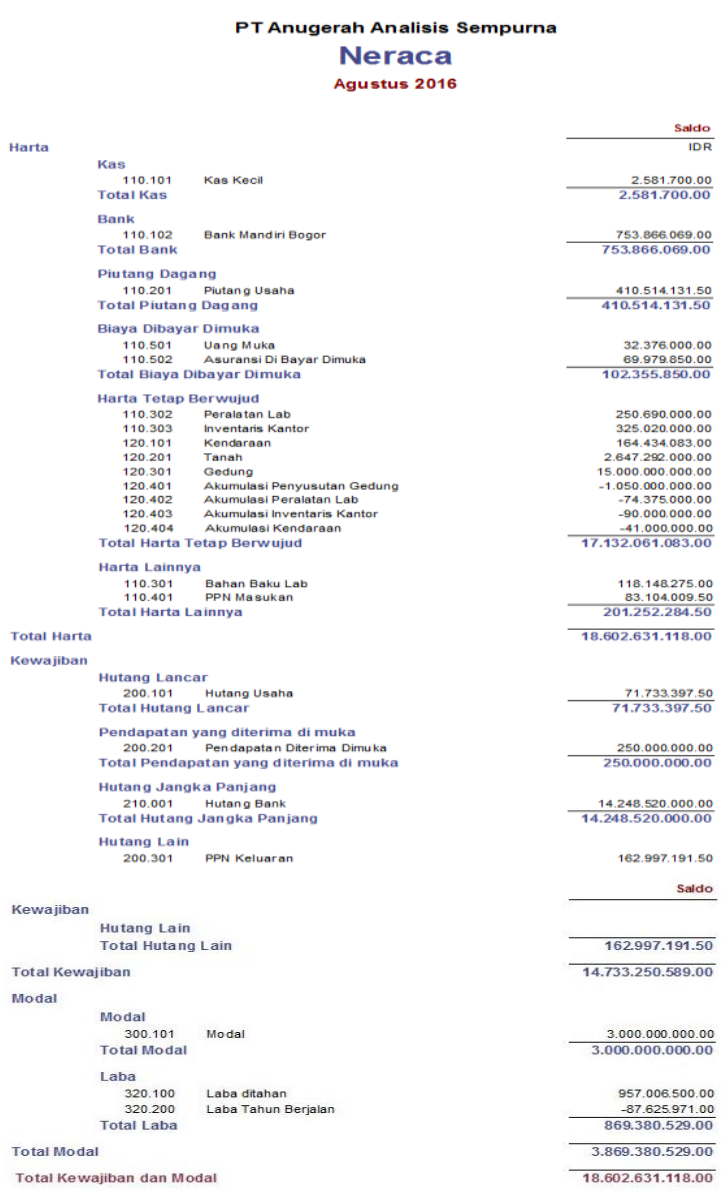

Gambar 23. Laporan Neraca

\section{KESIMPULAN DAN SARAN}

Setelah melihat permasalahan sistem yang sedang berjalan pada PT Anugerah Analisis Sempurna khususnya dalam pengolahan data akuntansi, maka penulis mengambil kesimpulan bahwa:

1. Pengolahan data akuntansi pada PT Anugerah Analisis Sempurna masih secara manual, sehingga pembuatan laporan keuangan menjadi tidak efektif dan efisien, sehingga menimbulkan hambatan dalam pembuatan laporan, karena membutuhkan waktu yang lama dalam penginputan dan pencarian data

2. Dengan sistem yang masih manual, memungkinkan adanya pekerjaan rangkap atau ganda, yang menimbulkan manipulasi serta kecurangan oleh seorang yang tidak bertanggung jawab.

3. Penggunaan Zahir Accounting Versi 5.1 dapat menjadi alternative pemecahan masalah dalam pengolahan data akuntansi pada PT Anugerah Analisis Sempurna. Mengurangi kesalahankesalahan yang dapat terjadi dalam pengolahan data yang dilakukan dan dapat mempercepat proses pengolahan data akuntansi.

4. Program zahir ini bisa mempercepat pembuatan laporan keuangan yang dilakukan PT Anugerah Analisis Sempurna, hanya tinggal memasukan 
data transaksi dapat menghasilkan jurnal, buku besar dan laporan keuangan.

5. Dalam hal penyimpanan data dikomputer menjadi lebih efektif, karena tidak banyak menggunakan media kertas untuk melakukan pencatatan, serta penyimpanan data menjadi lebih aman. Begitu pula jika kita ingin mencari data lebih muda dan cepat.

\section{SARAN}

Berdasarkan kesimpulan diatas. Penulis mencoba memberikan beberapa saran dengan harapan dapat bermanfaat dan membuat sistem dapat berjalan dengan baik. Saran penulis adalah sebagai berikut:

1. Perlu diadakannya pelatihan kepada karyawan yang akan menggunakan Zahir Accounting Versi 5.1, sehingga dapat pengoperasikan software ini secara optimal.

2. Dalam penggunaan aplikasi Zahir Accounting Versi 5.1 sangat diperlukan ketelitian dan kedisiplinan dari pemakai. Terutama dalam hal pemasukan data hendaknya sesuai dengan ketentuan yang benar, sehingga secara otomatis keluaran yang diperoleh sesuai dengan yang diharapkan.

3. Gunakan fasilitas persediaan yang disediakan Zahir Accounting Versi 5.1, sehingga lebih memudahkan dalam penggunaan barang yang akan digunakan, baik untuk kegiatan utama produksi atau untuk bahan-bahan pembantu

4. Dalam penggunaan aplikasi akuntansi, dalam hal ini yaitu Zahir Accounting Versi 5.1 disarankan untuk lebih memanfaatkan fasilitas pembuatan file back up sebagai cadangan data jika terjadi kehilangan file dan lain sebagainya. Gunakan fasilitas password yang telah disediakan oleh aplikasi Zahir Accounting Versi 5.1 sebagai pengaman data yang dimiliki perusahaan agar tidak disalah gunakan oleh pihak yang tidak berkepentingan.

\section{DAFTAR PUSTAKA}

Dunia, Firdaus A. (2008). Ikhtisar Lengkap Pengantar Akuntansi. Edisi Ketiga. Jakarta: Lembaga Penerbit FEUI.

Mulya, Haudri. (2013). Memahami akuntansi dasar pendekatan teknis siklus akuntansi. Jakarta: Mitra Wacana Media.

Rudianto. (2012). Pengantar Akuntansi. Jakarta: Erlangga.

Suradi. (2009). Akuntansi Pengantar 1. Yogyakarta: Gava Media.

Yulius, Hendri. (2011). 7 Langkah Praktis Membuat Pencatatan Akuntansi Keuangan Untuk
Perusahaan Jasa. Jakarta: PT Elex Media Komputindo.

Yuswanto, Lo Sanjaya. dan Hanafi. (2013). Komputerisasi Akuntansi dengan Zahir Accounting. Jakarta: PT Prestasi Pustakaraya. 